\title{
Fen Bilimleri Öğretmen Adaylarının Biyoloji Sınavlarındaki Soru Türlerine Yönelik Görüşleri
}

\author{
Aslı Görgülü Aråa, , Kevser Arslan
}

\section{Özet}

Bu araştırma, fen bilimleri öğretmen adaylarının, lisans seviyesindeki biyoloji sınavlarında kullanılan soru türlerine yönelik görüşlerinin belirlenmesi amacıyla gerçekleştirilmiştir. Araştırmanın çalışma grubunu, İstanbul'da bir devlet üniversitesinde öğrenim görmekte olan ve en az iki dönem biyoloji dersi almış olan 60 fen bilimleri öğretmen adayı oluşturmuştur. Çalışmada veri toplama aracı olarak, açık uçlu sorulardan oluşan görüşme formu kullanılmıştır. Öğretmen adaylarına, yarı yapılandırılmış görüşmeler aracılığı ile bu görüşme formundaki sorular yöneltilmiş, alınan cevapların analizinde betimsel analiz tekniği kullanılmıştır. Araştırmanın güvenirliliğini sağlamak için veriler iki alan uzmanı tarafından incelenmiş ve güvenirlik katsayısı \%87 olarak hesaplanmıştır. Elde edilen bulgulara göre, öğretmen adayları, en fazla çoktan seçmeli soru türlerinde, çeşitli nedenler ile kendilerini başarılı bulduklarını belirtmişlerdir. Öğrencilerin kendilerini farklı gerekçelerden ötürü boşluk doldurma soru türlerinde başarısız buldukları ön plana çıkmaktadır
Anahtar Kelimeler

Fen Bilimleri Öğretmen Adayları Biyoloji

Soru Türleri

Yarı-yapılandırılmış Görüşme

Makale Hakkında

Geliş Tarihi: 21.03.2019

Kabul Tarihi: 25.12.2020

Doi: 10.18026/cbayarsos.543140

\section{Opinions of Preservice Science Teachers About Question Types in Biology Exams}

\section{Abstract}

This study was carried out to determine the opinions of preservice science teachers about the types of questions used in the undergraduate level biology exams. The study group of the study consisted of 60 pre-service science teachers, who were studying at a state university in Istanbul and had taken biology courses for at least two semesters. An interview form consisting of open-ended questions was used as a data collection tool in the study. The questions in this interview form were asked to the pre-service teachers through semi-structured interviews, and the descriptive analysis technique was used in the analysis of the answers. In order to ensure the reliability of the study, the data were examined by two field experts and the reliability coefficient was calculated as $87 \%$. According to the findings, pre-service teachers stated that they found themselves successful for various reasons, mostly in multiplechoice question types. As the type of question they find unsuccessful, it is seen that the filling-in-the-blank question types stand out for different reasons.
Keywords

Preservice Science Teacher

Biology

Types of Questions

Semi-Structured Interviews

About Article

Received: 21.03.2019

Accepted: 25.12.2020

Doi: 10.18026/cbayarsos.543140

a İletişim Yazarı: agorgulu@yildiz.edu.tr

b Doç. Dr., Y1ldız Teknik Üniversitesi, https:// orcid.org/0000-0002-6034-3684

c Yüksek Lisans Öğrencisi, Yıldız Teknik Üniversitesi, https:// orcid.org/0000-0003-0658-7175 


\section{Giriş}

Öğretim faaliyetleri yürütülürken bireylere kazandırılması planlanan birçok hedef bulunmaktadır. Bireylere kazandırılması beklenilen bu hedeflerin kontrol edilmesi ise ancak doğru yapılmış bir ölçme ve değerlendirilme ile mümkün olabilmektedir. Ölçme, ölçülebilir bir niteliği gözlemlemek ve bu niteliği amacına uygun sayı ve sembollerle ifade etmektir. Öğretimde ölçme ise öğrencilerde ulaşılması istenen hedeflere yönelik uygun davranış değişikliğinin, hangi ölçüde meydana geldiğinin, çeşitli yöntemler ve sayılarla belirlenmesidir (Çepni, 2015). Değerlendirme ise, ölçme sonucu elde edilen verilerin pratikte ne anlam taşıdığ1 üzerine gerçekleştirilen yorumlama işlemidir (Çepni, 2015). Öğretimin vazgeçilmez bir parçası olan ölçme ve değerlendirme, eğitim sürecinin kontrolü ve devamlılı̆̆1 için kritik bir değere sahiptir (Başol, 2015). Dolayısıyla ölçme ve değerlendirmenin, tüm öğretim süreci içerisinde kilit nokta olduğu ve nitelik arayışının esas öğesini oluşturduğu söylenebilir. Bu doğrultuda öğretim sürecinde yinelenebilir ve güvenilebilir ölçme ve değerlendirme yöntemlerinin kullanılması gerekmektedir. Uygulanan öğretim programlarının etkililiğinin ortaya konulmasıyla birlikte öğrencilerin başarı durumlarının da belirlenmesine imkân tanınması ölçme ve değerlendirmeyle sağlanabilir. Nitekim öğretim sürecinde öğrenci başarısının ölçülmesi ve doğru bir biçimde değerlendirilmesi önemli bir konudur (Başol, 2015). Alan yazına bakıldığında ise en çok zorlanılan alanların başında ölçme ve değerlendirmenin geldiği görülmektedir (Benzer ve Eldem, 2013; Gaitas, Alves ve Martins, 2017).

Günümüz eğitim sisteminde, öğrenci başarısının belirlenmesi, eğitimciler aracıllı̆ıyla oluşturulmuş ölçme araçlarının öğrencilere uygulanıp ölçümlerin değerlendirilmesiyle sağlanabilmektedir. Dolayısıyla eğitimciler tarafından öğrencilerin başarı durumlarının ölçülmesinde çeşitli ölçme araçları kullanılmaktadır. Çoktan seçmeli sorular, kısa cevaplı (boşluk doldurma) sorular, eşleştirme soruları, doğru yanlış soruları, açık uçlu sorular öğretim programlarında yıllardır kullanılmakta olan geleneksel ölçme ve değerlendirme teknikleri olarak sayılabilir (Bahar, Nartgün, Durmuş ve Bıçak, 2014). Ölçme ve değerlendirmelerde uygulanan sınav türlerini; yazılı yoklama, sözlü yoklama, kısa cevaplı testler, eşleştirme maddeleri, doğru-yanlış testleri ve çoktan seçmeli testler olarak da siralayabiliriz (Tan, 2015).

Doğru-yanlış soru türleri; konuya ilişkin doğru veya yanlış olarak verilen bazı önermelerin öğrenciler tarafından okunarak, öğrencilerin önermenin doğru ve yanlış olduğuna karar vermeleri beklenilen soru türleri olarak tanımlanmaktadır (Tan, Kayabaşı ve Erdoğan, 2002; Yılmaz ve Sünbül, 2004). Diğer bir deyişle öğrencinin okuduğu önermeyi doğru veya yanlış olarak belirlediği soru tipidir. Soruda verilmiş olan önermelerin bir kısmının yanlış, bir kısmının ise doğru olması öğrencinin tahmin etme şansını doğurmaktadır (Uymaz, 2016).Ayrıca bu tür sorularda sadece iki yanıt seçeneğinin olması, doğru cevaba ulaşılmasında \%50 oranında bir ihtimalin var olmasını sağlar. Yanlış olarak verilen soru önermelerinde yer alan yanlış ifadenin bulunması veya yanlış ifadenin doğru olarak yazılması istenerek, bu tip sorulardaki şans başarısı azaltılabilir (Kaya-Uyanık ve Çalışkan, 2015).Tüm öğrencilerin her soruda ortak olan iki işaretleme yapacak olması hem maddelerin kolayca puanlanmasına hem de sonuçların objektif olarak değerlendirmesine fayda sağlayabilmektedir (Uymaz, 2016). Bu tür sorular bir konu alanındaki genellemeleri, karşılaştırmaları, olayların sebep sonuç ilişkilerini, olgu ve olay ilişkilerini, olayların 
sonuçlarıyla ilgili öngörüde bulunmayı ve bir sürecin basamaklarını değerlendirme amacıyla kullanılabilir (Bahar vd., 2010).

Boşluk doldurma soruları, soru kökünün devamında ya da altında bırakılan boşluğa, öğrencinin uygun cevabı yazmasının istendiği soru türü olarak açılanmaktadır (KayaUyanık ve Çalışkan, 2015). Diğer bir ifadeyle verilen önermelerde eksik olan bölümün uygun sözcüklerle doldurulduğu kısa cevaplı sorulardır. Bu tür soru önermelerine verilebilecek uygun yanıt; bir sözcük, rakam, tarih veya bir cümle olabilir (Tekin, 2009). Boşluğa uygun olarak verilebilecek yanıtın net olması, objektif ölçme yapılmasına olanak tanıyabilecek ve hata oranını da düşürebilecektir (Uymaz, 2016). Boşluk doldurma sorularının hazırlanma aşamasında güçlükler yaşanmasına karşın, kolay puanlanabilmesi, objektif sonuçlar elde edilebilmesi ve pek çok eğitim kademesinde kullanılabilmesi bu tür soruların sayılabilecek avantajlarındandır (Bahar vd., 2010). Her bir soru ifadesinin belirgin olması, soruların cevabının net olması, sorulan soruların sınavda yer alan diğer sorulara ipucu oluşturmaması, bir kazanımı veya beceriyi ölçebilmesi, her bir boşluk doldurma sorusuna bırakılan boşlukların aynı olması, sorunun alınmış olduğu kaynağın öğrenci tarafından tanınmaması bu tür sorularda güvenilir ve geçerli bir değerlendirme yapılabilmesi açısından önemli sayılmaktadır (Milli Eğitim Bakanlığı, 2005). Yalnızca bu tür soru türlerinin kullanıldığı bir araçla ölçme ve değerlendirme yapılması öğrenciyi ezbere yönlendirebileceği üzere üst düzey düşünme becerilerinin geliştirilmesi yönünde önemli eksiklikler ortaya çıkarabilecektir. (Bahar vd., 2010).

Çoktan seçmeli (test) soru türü; konuya ilişkin verilen soru köküne ait uygun olan yanıtın verilen seçenekler arasından seçildiği maddelerden oluşan soru türleri olarak tanımlanmaktadır (Gelbal, 2013). Çoktan seçmeli testler, testi hazırlayan kişilerin, soruna ait doğru cevabı seçenekler arasında verdiği ve cevaplayıcılar tarafından doğru cevabın bulunmasının istendiği testlerdir (Güler, 2017). Çoktan seçmeli testler, ülkemiz kapsamında gerçekleştirilen genel sinavlar da dâhil olmak üzere öğretmenlerin her derste öğrencilerin bilişsel alan davranışlarını tespit etmek amacıyla çoğunlukla tercih ettikleri soru türüdür (Karamustafaoğlu ve Tutar, 2016). Çoktan seçmeli sorular ortak köke ve seçeneğe sahip bir şekilde, bileşik cevaplı, eksik köklü, olumsuz ifadelerin yer aldığı, doğru cevabı gizlenmiş gibi birçok biçimde hazırlanabilmektedir (Kaya-Uyanık ve Çalışkan, 2015). Çoktan seçmeli soruların fazla sayıda madde içerebilmesi konu alanındaki kritik kazanımları kapsamasına dolayısıyla da kapsam geçerliğinin yüksek olmasına olanak tanımaktadır (Güler, 2017). Kalabalık gruplara yönelik yapılacak ölçme ve değerlendirmelerde puanlama güvenirliğinin sağlaması çoktan seçmeli testlerle daha basittir (Klufa, 2015). Çoktan seçmeli soruların kısmi puanlama içermemesi ve cevabın kesin olması, daha objektif bir puanlama yapabilme olanağı da tanımaktadır (Turgut ve Baykul, 2012). Ayrıca hemen puanlanabiliyor olması okullara, öğretmenlere ve öğrencilere hızlı sonuç verilebilmesini sağlar (Birgili, 2014). Çoktan seçmeli testler bazı durumlarda doğru cevabı bilmeyen bir öğrencinin doğru cevaba ulaşmasını sağlayabilir. Seçenekler arasında rastgele seçim yapılarak, doğru cevap bulunabilmektedir. Bu durum şans başarısı olarak açıklanabilir. Ortaya çıkabilecek şans faktörünün en aza indirilmesinde seçenek sayısının artırılması veya üç ya da dört yanlışın bir doğruyu götürmesi şeklinde uygulamalardan faydalanılabilmektedir (Kaya-Uyanık ve Çalışkan, 2015). Soru kökünün sadece bir beceriye odaklanması, soru kökünün açı olması, soru kökünde gereksiz ifadelerden kaçınılması, soru kökünde herhangi bir ipucunun bulunmaması, dil ve anlatım açısından uygun olması, cevapların objektif olması, tuzak sorulara yer verilmemesi, çeldiricilerin doğru cevaba yakın olmasına ve seçeneklerin 
birbirinden bağımsız olmaması bu tür soru tipinde dikkat edilmesi gereken hususlar olarak sayılabilir (Milli Eğitim Bakanlığı, 2005).

Açık uçlu sorular; konuya ilişkin verilen soruların öğrenciler tarafından belirlenen süre zarfında yazılı olarak cevaplandırılması beklenen soru türleridir (Uymaz, 2016). Eğitimde yaygın şekilde kullanılmakta olan ölçme araçlarından biri olan açı uçlu maddelerdir (Güler, 2014). Hazırlanması kolay olduğundan eğitim öğretim sürecinde öğretmenler tarafından sıklıkla tercih edildiği söylenebilir. Konu alanının yapılandırılmasında temel kavramları, süreçleri ve becerileri ifade edebilen soru tipleridir. Genel anlamda açık uçlu sorular karmaşık düşünmeyi gerektirir ve ürün olarak birden fazla sonuç verebilir. Bu tür sorular, puanlayıcının yanıtları birden fazla ölçütü dikkate alarak yorumlamasını ve değerlendirmesini gerektirmektedir (Budak, 2019). Yalnızca soruların verilmiş olması ve cevabın öğrenci tarafından düşünülüp yazılması öğrencilerin doğru cevap verme şansını düşürecektir (Kaya-Uyanık ve Çalışkan, 2015). Açık uçlu sorular, ölçmeyi yapacak kişiler tarafından diğer soru türlerine kıyasla daha kolay hazırlanabilmektedir (Başol, 2015). Öte yandan açık uçlu soruların diğer soruların aksine öğrencilerin zihinsel beceri ve düşünme süreci geliştirebilmektedir (Karaca, 2012). Soruların kesin bir çözümü bulunmamakla birlikte, tek doğru cevabı da yoktur, bu tip soruların çözümü, çok yönlü düşünmeyi disiplinler arası bilgiyi ve yaratıcılı̆̆ı gerektirmektedir (İlhan, 2015).

Alan yazın incelendiğinde, Uymaz ve Çalışkan (2019), tarafından gerçekleştirilen bir çalışmada, sosyal bilgiler öğretmenlerinin sınavlarda sordukları soru türlerinin ve kapsam geçerliğinin incelenmesi amaçlanmıştır. Çalışma sonucunda sınavlarda genellikle çoktan seçmeli, en az ise açık uçlu soruların kullanıldığı belirlenmiştir. Ayrıca soruların hem üniteler hem de kazanımlar açısından kapsam geçerliğinin yeterli olmadığı tespit edilmiştir. Akyıldız ve Karadağ (2018) tarafından gerçekleştirilen bir çalışmada, güçlük ve ayırt ediciliklerin soru türüne göre anlamlı farklılık gösterip göstermediğinin ortaya konulması amaçlanmıştır. Çalışma sonucunda boşluk doldurma sorularının diğer sorulara göre daha kolay ve daha ayırt edici olduğu ortaya konulmuştur. Budak (2019), tarafından yapılan çalışmada, fen bilimleri eğitiminde kullanılan açık uçlu soruların puanlanmasında puanlayıcılar arasındaki ilişkinin incelenmesi amaçlanmıştır. Araştırma sonucunda, her bir açık uçlu soru için, puanlayıcılar arasında pozitif yönde, yüksek ve anlamlı bir ilişki bulunmuş. Puan ortalamaları arasında anlamlı farklılıklar tespit edilmiştir. Diken ve Yuruk (2019), tarafından gerçekleştirilen çalışmada, 9. sınıf öğrencilerinin fen bilimleri alanındaki çoktan seçmeli soruların çözümü öncesi, çözümü sırasında ve çözüm sonrasındaki süreçlerde kullandıkları bilişsel ve üst bilişsel stratejilerin belirlenmesi amaçlanmıştır. Çalışma sonucunda Fen Lisesi öğrencilerinin çoktan seçmeli soruların çözümü öncesi ve çözümü sırasındaki süreçlerde diğer liselere göre fazla sayıda bilişsel ve üst bilişsel strateji kullandıkları ortaya konulmuştur. Ayrıca soruların çözümü sonrasında öğrencilerin tamamının bilişsel strateji kullanmadıkları tespit edilmiştir. Öksüz ve Güven-Demir (2019), yapılan araştırmada açık uçlu ve çoktan seçmeli başarı testlerinin psikometrik özellikler ve öğrenci performansı açısından karşılaştırılması amaçlanmıştır. Aynı üniteye ilişkin olarak geliştirilen ölçme araçları arasında madde güçlük, madde ayırıcılık, öğrenci performansı, cinsiyet açısından anlamlı farklılık bulunmuştur.

Bununla birlikte literatürde öğrencilere ve öğretmenlere yönelik gerçekleştirilen araştırmalar olduğu görülürken, lisans döneminde önemli olarak görülebilecek pek çok Latince kelimeyi bünyesinde barındıran biyoloji alanına dâhil edilen anatomi sınavında sorulan soru tiplerine 
ilişkin bir çalışma yer almaktadır. Görgülü-Arı ve Arslan (2019) tarafından gerçekleştirilen çalışmada fen bilgisi öğretmen adaylarının anatomi dersi sınavlarında uygulanan soru tiplerine yönelik görüşleri ortaya çıkarılması amaçlanmıştır.

Ülkemizde fen bilimleri biyoloji, fizik ve kimya temel alanlarının birleşimi olarak belirlenmiştir. Bu çalışmada da fen bilimlerinin biyoloji alanı ele alınmıştır. Öğrencilerin zihinsel süreçlerini anlamak ve öğrenme düzeylerini tespit etmek açısından sınavlarda sorulmuş olan soruların incelenmesi oldukça önemlidir (Çalışkan, 2011). Sınavda sorulmuş olan soru türlerini analiz etmek, öğrencilerin zihinsel gelişim süreçlerinin anlaşılması ve öğrenme düzeylerinin tespit edilmesi konularında eğitimcilere önemli ipuçları sunabilecektir (Şanlı ve Pınar, 2017). Buradan hareketle, sınavlardaki soruların niteliklerinin irdelenmesi kadar sorulan soruların türlerinin de incelenmesinin alan yazın açısından önemli olabileceği düşünülmektedir. Bu nedenle bu araştırma verileri ile henüz netlik kazanılmamış olan bu konuya da dikkat çekilmek istenmiştir. Biyoloji dersinin fen bilimleri öğretmen adayları açısından önemi düşünüldüğünde, bu konuda yapılacak bir ölçmenin de doğru ve etkin bir biçimde yapılması gerektiği yadsınamaz. Bu çalışmada, biyoloji alanında sorulmuş olan soru tiplerine yönelik öğretmen adayı görüşlerinin, öğretim üyeleri başta olmak üzere biyoloji alanında eğitim veren bireylere fayda sağlayabileceği düşünülmüştür. Elde edilen öğretmen adayı görüşlerinin, soru tiplerinde var olan teknik veya uygulamaya dayalı eksikliklerin giderilmesine katkı sağlayabileceği beklenmektedir. Bu doğrultuda, bu araştırma, Fen Bilgisi öğretmen adaylarının biyoloji dersi kapsamında, dersin ölçme kısmında yer alan sınavlarda seçilmiş olan soru tiplerine yönelik görüşlerinin belirlenmesini amaçlamaktadır.

Araştırmanın amacından hareketle, araştırma ana problemi ve alt problemlerine cevap aranmıştır. Araştırmada cevap aranan araştırma ana problemi; "fen bilimleri öğretmen adaylarının, biyoloji sınavlarında sorulan soru türlerine ilişkin görüşleri nelerdir?" şeklinde belirlenmiştir.

Ana probleme dayalı olarak oluşturulan araştırma alt problemleri sırasıyla verilmiştir.

a. Fen bilimleri öğretmen adaylarının, biyoloji sınavlarındaki doğru-yanlış türü sorulara ilişkin görüşleri nedir?

b. Fen bilimleri öğretmen adaylarının, biyoloji sınavlarındaki boşluk doldurma soru türüne ilişkin görüşleri nedir?

c. Fen bilimleri öğretmen adaylarının, biyoloji sınavlarındaki çoktan seçmeli(test) soru türüne ilişkin görüşleri nedir?

d. Fen bilimleri öğretmen adaylarının, biyoloji sınavlarındaki açık uçlu soru türüne ilişkin görüşleri nedir?

\section{Yöntem}

\section{Araştırma Modeli}

Araştırmada nitel araştırma desenlerinden genel tarama yöntemi tercih edilmiştir. Tarama yöntemi, geçmişte ya da halen var olan bir durumun olduğu şekliyle betimlenmesini amaçlayan bir yaklaşımdır (Karasar, 2016). Betimsel çalışmalar ile çalışılan olguya dair bireylerin tutum, görüş veya davranışlarının ortaya çıkarılması amaçlanmaktadır (Creswell, 2013). 


\section{Çalışma Grubu}

Araştırmanın katılımcıları, İstanbul'da yer alan bir devlet üniversitesi, eğitim fakültesi, fen bilimleri öğretmenliği ana bilim dalında, 2. sınıfta öğrenim gören, 51'i kız, 9'u erkek olmak üzere toplam 60 öğretmen adayından oluşmaktadır.

Araştırmanın çalışma grubunu oluşturan katılımcıların belirlenmesinde amaçlı örnekleme yöntemlerinden ölçüt örnekleme yönteminden faydalanılmıştır. Ölçüt örnekleme, örneklemin problemle ilgili olarak belirlenen niteliklere sahip kişiler, olaylar, nesneler ya da durumlardan oluşturulmasıdır (Büyüköztürk, Kılıç-Çakmak, Akgün, Karadeniz ve Demirel, 2008). Ölçüt örnekleme yönteminde önceden belirlenmiş bir dizi ölçütü karşılayan bütün durumlar çalışılır. Ölçüt ya da ölçütler araştırmacı tarafindan oluşturulabilir ya da daha önceden hazırlanmış bir ölçüt listesi kullanılabilir (Yıldırım ve Şimşek, 2016). Bu doğrultuda gerçekleştirilen bu araştırmada ise çalışma grubunun belirlenmesinde fen bilimleri öğretmen adaylarının biyoloji dersini en az iki dönem lisans seviyesinde almış ve dönem sonunda gerçekleştirilmiş olan biyoloji sınavına girmiş olmaları ölçütü dikkate alınmıştır. Çalışmaya katılım sağlayan öğretmen adayları belirlenirken, adayların gönüllük esası göz önüne alınmıştır.

\section{Veri Toplama Araçları}

Araştırmada veri toplama aracı olarak 4 adet açık uçlu sorulardan oluşan görüşme formu kullanılmıştır.

Açık uçlu sorular bir taraftan araştırmacıya araştırmak istediği konuyla ilgili esnek bir yaklaşım olanağı sağlarken bir taraftan da incelenen konuyla ilgili önemli değişkenlerin gözden kaçmasını önler (Yıldırım ve Şimşek, 2016). Açık uçlu sorular yanıtlayıcının gerçekten ne düşündüğüne ilişkin daha doğru bilgi sağlamaktadır (Johnson, 2014). Ayrıca açık uçlu sorular; bireylerin deneyim, fikir ve duygularını tanımlarken kullandıkları tema, imge ve kelimeleri inceleme fırsatı sunması açısından oldukça önemlidir (Patton, 2014). Buradan hareketle çalışmada veri toplama aracı olarak açık uçlu soru maddelerinden oluşan bir görüşme formundan faydalanılması uygun görülmüştür.

Araştırmacılar tarafından hazırlanan 4 adet açık uçlu soru maddelerinden oluşan ölçme aracı, fen eğitimi alanında uzman iki öğretim üyesinin incelemesine sunulmuştur. Alınan uzman görüşleri doğrultusunda gerekli düzenlemeler ve değişiklikler yapılmıştır. Öte yandan dil ve anlatım açısından kontrol sağlanmış, soru soruluş ve ifade biçimleri bakımından yeniden düzenlenmiştir. Sonraki aşamada ise son hali verilen veri toplama aracı, çalışma grubu ile aynı özellikleri taşıyan ancak çalışma için yapılacak uygulamada yer almayacak olan, 5 öğretmen adayına okutulmuş ve anlamsal olarak sorulardan ne anladıkları sorgulanmıştır. Böylelikle esas uygulama sırasında ortaya çıkabilecek olumsuz durumların önüne geçilmiş ve öğretmen adayları için uygunluğu test edilmiştir.

Son hali verilen görüşme formunda bulunan sorular, sırasıyla aşağıda verilmiştir.

a. Biyoloji sınavında, sorulan doğru-yanlış türü sorulara yönelik görüşleriniz nelerdir? Kendinizi bu tür sorularda başarılı görüyor musunuz?

b. Biyoloji sinavında, sorulan boşluk doldurma türü sorulara yönelik görüşleriniz nelerdir? Kendinizi bu tür sorularda başarılı görüyor musunuz? 
c. Biyoloji sınavında, sorulan çoktan seçmeli (test) türü sorulara yönelik görüşleriniz nelerdir? Kendinizi bu tür sorularda başarılı görüyor musunuz?

d. Biyoloji sınavında, sorulan açık uçlu soru türüne yönelik görüşleriniz nelerdir? Kendinizi bu tür sorularda başarılı görüyor musunuz?

Veri toplama aşaması öncesi öğretmen adaylarına gerekli açılamalar yapılmıştır. Daha sonra çalışmaya gönüllü olarak katılım sağlayan 60 öğretmen adayı ile yarı yapılandırılmış görüşmeler yapılarak veriler toplanmıştır. Her bir görüşme süresi ortalama 20 dakika sürmüştür. Veri toplama süreci sonunda öğretmen adaylarının isimleri saklı tutularak, öğretmen adaylarının her biri “Ö1, Ö2... Ö60" şeklinde kodlanıp sorulara verdikleri cevaplardan yapılan doğrudan alıntılara yer verilmiştir.

\section{Verilerin Analizi}

Araştırmaya katılan öğretmen adayları ile yapılan yarı yapılandırılmış görüşmeler yardımıyla elde edilen veriler betimsel analiz yöntemi ile analiz edilmiştir. Betimsel analiz, çeşitli veri toplama teknikleri ile elde edilmiş verilerin daha önceden belirlenmiş temalara göre özetlenmesi ve yorumlanmasını içeren bir nitel veri analiz türüdür. Betimsel analizde birbirine benzeyen veriler, belirli kavramlar ve kategoriler çerçevesinde bir araya getirilir ve bunları anlaşılabilecek şekilde düzenlenerek yorumlanır. Bu sayede veriler tanımlanır, verilerin içinde saklı olabilecek gerçekler ortaya çıkarılır (Yıldırım ve Şimşek, 2016). Kodlama veri analizinde yapılması gereken en temel işlemdir, veriler arasındaki ilişkileri keşfetmeyi sağlar (Punch, 2014).

Bu bağlamda her bir öğretmen adayına ait görüşme ses kayıt cihazı ile kayıt altına alınmış ve ayrıca görüşme esnasında gerekli notlar alınmıştır. Görüşler analiz edilirken, benzer kavramlar bir araya getirilmiş, kodlar oluşturulmuştur. Oluşturulan kodlar tekrar gözden geçirilmiş ve düzenlenmiştir. Her bir benzer kod ayrı bir kategori altında toplanmıştır. Daha sonra bu kodlar tekrar detaylı olarak okunmuş, kodları açıklayan kategoriler oluşturulmuş ve kategori başlıkları belirlenmiştir. Daha sonra ise kodlanan ve ardından kategoriler halinde değerlendirilen verilerin frekans dağılımları hesaplanmıştır. Her bir soru ve sorulara verilen yanıtları için tablolar oluşturulmuştur. Bir öğretmen adayının birden fazla koda uygun cevap vermesi durumunda, frekans dağılımları her bir kod için ayrı ayrı sunulmuştur.

\section{Güvenirlik}

Güvenirliliği sağlamak için veriler çalışma grubunda olmayan bir akademisyen tarafından daha inceleniş ve oluşturulan tema ile kodlarla uyum olup olmadığına bakılmıştır. Farklı araştırmacıların aynı verileri yorumlayarak kodlar ve kategoriler oluşturulması ve bunların kıyaslanması güvenirliğin sağlanması açısından önemlidir (Erişti, 2014; Merriam, 2013). Her iki araştırmacı tarafından oluşturulmuş kod ve kategoriler belirlenmiştir. Belirlenen kod ve kategoriler incelenmiş ve birbiriyle karşılaştırılmıştır. Sonraki aşamada Miles ve Huberman'ın (1994) güvenirlik formülü kullanılarak verilerin güvenirlik hesaplaması yapılmıştır (Güvenirlik: Görüş Birliği / Görüş Birliği+Görüş Ayrılığı). Güvenirlik kat sayısı fikir birliği bulunanların, fikir birliği bulunan ve fikir birliği bulunmayanların toplamına bölünüp 100 ile çarpılmasıyla hesaplanmaktadır. Gerçekleştirilen hesaplamalar sonucunda elde edilen güvenirlilik kat sayısı \%87 olarak hesaplanmıştır. Güvenirlik düzeyi \%70 ve üstünde elde edilen değerler araştırmanın güvenirliliğinin sağlanması açısından yeterli görülmektedir (Yıldırım ve Şimşek, 2016). Dolayısıyla da çalışma verilerinden elde edilen 
güvenirlik kat sayısının yüksek olduğu söylenebilir. Ayrıca araştırma tutarlılığının (iç güvenirliğini) sağlanması açısından öğrencilerin veri toplama araçlarındaki sorulara verdikleri yanıtlardan alıntılar eklenmiştir.

Gerçekleştirilen araştırma kapsamında bazı unsurlar açısından, araştırmanın sahip olduğu sinırlılıklar maddeler halinde belirtilmiştir.

Araştırma;

— devlet üniversitesinde öğrenim görmekte olan 60 fen bilimleri öğretmen adayı ile,

- hazırlanan 4 adet açı uçlu maddeden oluşan bir ölçme aracı ile,

- biyoloji sınavına ilişkin olarak alınan görüşler ile,

— fen bilimleri öğretmen adaylarının ölçme aracındaki sorulara verdikleri cevaplar ile sinırlıdır.

\section{Araştırmada Etik Süreçler}

Gerçekleştirilen araştırma çerçevesinde, Yıldız Teknik Üniversitesi Sosyal ve Beşeri Bilimler Etik Kurulu'ndan (Say1: 73613421-604.01.02-BABBFCF3) ve Yıldız Teknik Üniversitesi Rektörlüğü'nden izin alınmıştır. Araştırmaya gönüllü olarak katılım sağlayan öğrencilerden alınan cevapların gizlilik ilkesinin çiğnenmeyeceği, elde edilen verilerin bilimsel araştırma dışında diğer amaçlarla asla kullanılmayacağı ve araştırmacı tarafından kontrolünün her basamakta sağlanacağı açıklanmıştır. Ayrıca yanıtlayıcıların isimleri alınmayarak, kimliklerinin gizleneceği konusunda güvence verilmiştir.

\section{Bulgular}

\section{Doğru-Yanlış Soru Türüne İlişkin Görüşler}

Fen Bilimleri öğretmen adaylarının, doğru-yanlış sorularına ilişkin görüşlerini belirlemeye yönelik yararlanılan yarı yapılandırılmış görüşmelerden elde edilen verilerin betimsel analiz sonuçları Tablo 1'de sunulmuştur.

Tablo 1:Fen Bilimler Öğretmen Adaylarının Doğru-Yanlış Sorularına İlişkin Görüşleri

\begin{tabular}{llc}
\hline Kategori & Kod & Frekans(f) \\
\hline Akademik & Başarılı olduğumu düşünüyorum & 49 \\
\cline { 2 - 3 } Başarı & Başarısız olduğumu düşünüyorum & 11 \\
\hline Bilgilerin & Cümle okununca cevabın hatırlanması & 35 \\
\cline { 2 - 3 } Hatırlanması & Sorudaki anahtar kelimelerin cevabı & 17 \\
& hatırlatması & 29 \\
\hline Şans Başarısı & \%50 cevap şansı bulunması & 21 \\
\cline { 2 - 3 } & Cevabın kolay tahmin edilebilmesi & 25 \\
\hline İçerik- & Detaylı bilgi gerektirmemesi & 12 \\
\cline { 2 - 3 } Kapsam & Ayrıntılı sorulmadı̆̆ından kolayca & \\
\hline & yapılabilmesi & \\
\hline
\end{tabular}




\begin{tabular}{lll}
\hline Ezberci & Doğrudan ezber gerektirmemesi & 10 \\
Yaklaşım & & \\
\hline Gözden & Soruda değiştirilen yerin göze & 7 \\
Kaçırma & çarpmaması & \\
\cline { 2 - 3 } & Tüm önermelerin doğru gibi görünmesi & 4 \\
\hline
\end{tabular}

Tablo 1'de, fen bilimleri öğretmen adaylarının doğru-yanlış soru türüne ilişkin görüşlerine ait verileri, "Akademik Başarı", “Bilgilerin Hatırlanması", “Şans Başarısı”, “İçerik-Kapsam”, "Ezberci Yaklaşım" ve "Gözden Kaçırma" olmak üzere 6 kategori altında toplanmıştır. Yarıyapılandırılmış görüşmeler sırasında bir aday birden fazla koda uyan görüş bildirebilmiştir ve bu görüşler uygun olan kodlarla ifade edilmiştir. Bu kategorilerdeki kod dağımları ise şu şekildedir: Doğru yanlış sorularında akademik başarı, kategorisi altında öğretmen adaylarının 49'u "başarılı olduğumu düşünüyorum", 11'i ise "başarısız olduğumu düşünüyorum" şeklinde görüş belirtmiştir. Bilgilerin hatırlanması kategorisi altında öğretmen adaylarının 35'i "cümle okununca cevabın hatırlanması", 17'si ise "sorudaki anahtar kelimelerin cevabı hatırlatması" kodlarına uygun olacak şekilde görüş belirtmiştir. Şans başarısı kategorisi altında öğretmen adaylarının 29'u "\%50 cevap şansı bulunması", 21'i ise "cevabın kolay tahmin edilebilmesi" kodlarına uygun olacak şekilde görüşünü ifade etmiştir. İçerik-kapsam kategorisi altında öğretmen adaylarının 25'i "detaylı bilgi gerektirmemesi", 12 'si ise "ayrıntılı sorulmadığından kolayca yapılabilmesi" kodlarına uygun olacak şekilde görüş belirtmiştir. Ezberci yaklaşım kategorisi altında öğretmen adaylarının 19'u "doğrudan ezber gerektirmemesi" koduna uygun olacak şekilde görüşünü ifade etmiştir. Gözden kaçırma, kategorisi altında öğretmen adaylarının 7'si "soruda değiştirilen yerin göze çarpmaması", 4'ü ise "tüm önermelerin doğru gibi görünmesi" kodlarına uygun olacak şekilde görüşlerini açıklamışlardır.

Öğretmen adaylarının cevaplardan alınan doğrudan alıntılardan bazılarına aşağıda verilmiştir.

Öğretmen adayı Ö5, “Doğru yanlış sorularında verilen cümleyi okuyunca cevabı anımsıyorum, çünkü bu tür sorularda zaten verilebilecek tüm bilgi oluyor, bize de sadece bu cümleler hakkında fikir yürütmek kalıyor ve ben bu konuda kendimi başarılı buluyorum" şeklinde görüş belirtmiştir.

Öğretmen adayı Ö49, "Sınavda sorulan konu hakkında azda olsa bir bilgim varsa, yarı yarıya şansım olduğundan bu tarz sorularn yapabiliyorum ve b tarz sorularda başarı şansım da yüksek oluyor" şeklinde görüşünü açıklamıştır.

Öğretmen adayı 25 ise, "Ben istesem de bu tür sorularda başarılı olamıyorum çünkü dersin öğretim üyesi öyle bir yerinde değişiklik yapıyor ki sanki o sorunun cevabı bana her zaman doğru gibi geliyor" şeklinde görüşünü ifade etmiştir.

\section{Boşluk Doldurma Soru Türüne İlişkin Görüşler}

Fen bilimleri öğretmen adaylarının, boşluk doldurma sorularına ilişkin görüşlerinin betimsel analiz sonuçları Tablo 2' de sunulmuştur. 
Tablo 2: Fen Bilimler Öğretmen Adaylarının Boşluk Doldurma Sorularına İlişkin Görüşleri

\begin{tabular}{|c|c|c|}
\hline Kategori & Kod & Frekans(f) \\
\hline Akademik & Başarısız olduğumu düşünüyorum & 51 \\
\hline Başarı & Başarılı olduğumu düşünüyorum & 9 \\
\hline İçerik- & Detaylı bilgi gerektirmesi & 29 \\
\hline \multirow[t]{3}{*}{ Kapsam } & Sorulabilecek fazla konu barındırması & 16 \\
\hline & Konunun tamamina hâkim olma & 12 \\
\hline & zorunluluğu & \\
\hline Belleğe Bilgi & Bilgiyi öğrenmede zihin karmaşası & 24 \\
\hline \multirow[t]{2}{*}{ Kodlama } & oluşturması & \\
\hline & Doğru şekilde hafızada tutamama & 19 \\
\hline Teknik & Latince kelimelerin karıştırılabilmesi & 20 \\
\hline Terimler & $\begin{array}{l}\text { Yabancı terimlerde yazım hatası } \\
\text { yapılması }\end{array}$ & 17 \\
\hline \multirow[t]{2}{*}{ Şans Başarısı } & Tahmin edebilme imkânı olmaması & 18 \\
\hline & Yorum odaklı cevap yazılamaması & 11 \\
\hline Çalışma & Detaylı ve verimli çalışılamaması & 16 \\
\hline Güçlüğü & $\begin{array}{l}\text { Bu tipte çıkabilecek sorulara çalışırken } \\
\text { fazla zaman ayrılması zorunluluğu }\end{array}$ & 9 \\
\hline Ezberci & Ezbere dayalı olması & 12 \\
\hline Yaklaşım & Ezber yeteneği gerektirmesi & 8 \\
\hline \multirow[t]{2}{*}{ Bilgiyi Ölçen } & Tam anlamıyla çalışanı ayırt edebilmesi & 7 \\
\hline & $\begin{array}{l}\text { Tanım soruları için bilginin ölçülmesini } \\
\text { sağlaması }\end{array}$ & 4 \\
\hline
\end{tabular}

Tablo 2'de, fen bilimleri öğretmen adaylarının boşluk doldurma soru türüne ilişkin görüşlerine ait verileri, "Akademik Başarı", "İçerik-Kapsam", "Belleğe Bilgi Kodlanması", "Teknik Terimler", "Şans Başarısı", "Çalışma Güçlügü̈", "Ezberci Yaklaşım" ve "Bilgiyi Ölçen" olmak üzere 8 kategori altında toplanmıştır. Yarı-yapılandırılmış görüşmeler sırasında bir aday birden fazla koda uyan görüş bildirebilmiştir ve bu görüşler uygun olan kodlarla ifade edilmiştir. Bu kategorilerdeki kod dağılımları ise şu şekildedir: Boşluk doldurma sorularında akademik başarı, kategorisi altında öğretmen adaylarının 51'i "başarılı olduğumu düşünüyorum", 9'u ise "başarısız olduğumu düşünüyorum" şeklinde görüş belirtmiştir. İçerik-kapsam kategorisi altında öğretmen adaylarının 29'u "detaylı bilgi gerektirmesi", 16'sı "sorulabilecek fazla konu barındırması" 12'si ise "konunun tamamına hâkim olma zorunluluğu" kodlarına uygun olacak şekilde görüş belirtmiştir. Belleğe bilgi kodlama 
kategorisi altında öğretmen adaylarının 24'ü "bilgiyi öğrenebilmede zihin karmaşası", 19'u ise "doğru şekilde hafızada tutamama" kodlarına uygun olacak şekilde görüşlerini açıklamışlardır. Teknik terimler kategorisi altında öğretmen adaylarının 20'si "Latince kelimelerin karıştırılabilmesi", 17'si ise "yabancı terimlerde yazım hatası yapılması" kodlarına uygun olacak şekilde görüş belirtmiştir. Şans başarısı kategorisi altında öğretmen adaylarının 18'i "tahmin edebilme imkânı olmaması", 11'i "yorum odaklı cevap yazılamaması" koduna uygun olacak şekilde görüşünü ifade etmiştir. Çalışma güçlüğü, kategorisi altında öğretmen adaylarının 16'sı "detaylı ve verimli çalışılamaması", 9'u ise "bu tipte çıkabilecek sorulara çalışırken fazla zaman ayrılması zorunluluğu" kodlarına uygun olacak şekilde görüşlerini açıklamışlardır. Ezberci yaklaşım kategorisi altında öğretmen adaylarının 12'si "ezbere dayalı olması", 8'i ise "ezber yeteneği gerektirmesi" kodlarına uygun olacak şekilde görüş belirtmiştir. Bilgiyi ölçen kategorisi altında öğretmen adaylarının 7'si "tam anlamıyla çalışanı ayırt edebilmesi", 4'ü ise "tanım soruları için bilginin ölçülmesini sağlaması" kodlarına uygun olacak şekilde görüşlerini açılamışlardır.

Öğretmen adaylarının bu konuya ilişkin verdikleri cevaplardan yapılan doğrudan alıntılara aşağıda yer verilmiştir.

Öğretmen adayı Ö55, "Bu soru türünde çok fazla bilgi gerekiyor ve sorulan konu hakkında her şeyi bilmem gerekiyor, ama ben ezberleme yeteneğinde biri değilim, illa ki her şeyi anlayarak öğrenmeliyim, $b$ sorularda bana göre çok zor geliyor ve bu nedenle bu sorularda kendimi başarıl görmüyorum" şeklinde görüşünü belirtmiştir.

Öğretmen adayı Ö22 ise, "Biyoloji dersi çok Latince bilgi içeriyor ve bu derste ister istemez kelime hataları yapabiliyoruz, bu nedenle ileride kedi öğrencilerime de kendim başarısız olduğumu düşündüğ̈̈m bu soru türünden sormayı düşünmüyorum" şeklinde görüş bildirmiştir.

Öğretmen adayı 8,"Ben sınavlara çok detaylı çalışıyorum ve tüm soruların içinde özellikle bu sor türünün gerçekten çalışan ayırt ettiğini düşünüyorum, atıp tutma şansı da yok, bu nedenle benim gibi çalışan birini diğerlerinden ayırıyor ve bu da benim başarılı olduğum soru türleri olarak bu soru türünü kabul etmeme neden oluyor" şeklinde görüş bildirerek boşluk doldurma türündeki sorular hakkındaki görüşünü açıklamıştır.

\section{Çoktan Seçmeli (Test) Soru Türüne İlişkin Görüşler}

Fen bilimleri öğretmen adaylarının, çoktan seçmeli (test) sorulara ilişkin görüşlerini açığa çıkarmaya yönelik yarı yapılandırılmış görüşmelerden elde edilen verilerin betimsel analiz sonuçları Tablo 3' de sunulmuştur.

Tablo 3: Fen Bilimler Öğretmen Adaylarının Çoktan Seçmeli (Test) Sorularına İlişkin Görüşleri

\begin{tabular}{llc}
\hline \multicolumn{1}{c}{ Kategori } & \multicolumn{1}{c}{ Kod } & Frekans (f) \\
\hline \multirow{2}{*}{ Akademik Başarı } & Başarılı olduğumu düşünüyorum & 57 \\
\cline { 2 - 3 } & Başarısız olduğumu düşünüyorum & 3 \\
\hline \multirow{2}{*}{ Bilgilerin } & Tüm şıkların göz önünde olması & 51 \\
Hatırlanması & sayesinde cevabın hatırlanması & \\
\cline { 2 - 3 } & Şılkarın bazılarının iliş̧isiz olması & 5 \\
\hline
\end{tabular}




\begin{tabular}{lll}
\hline & \multicolumn{2}{l}{ sayesinde cevabın hatırlanması } \\
\hline Geçmiş Kazanımlar & Test tekniğine yatkın olma & 47 \\
\hline \multirow{2}{*}{ İcrik-Kapsam } & Detaylı bilgi gerektirmeme & 29 \\
\cline { 2 - 3 } & Test sorusu olabilecek konuyu & 18 \\
\hline Şans Başarısı & öngörebilme & \\
\hline Çeldiriciler & Rastgele işaretleme ile doğruya & \\
\hline & ulaşma imkânı olması & 3 \\
\hline
\end{tabular}

Tablo 3'te, fen bilimleri öğretmen adaylarının çoktan seçmeli (test) soru türüne ilişkin görüşlerine ait verileri, "Akademik Başarı", "Bilgilerin Hatırlanması", Geçmiş Kazanımlar", "İçerik-Kapsam", "Şans Başarısı" ve "Çeldiriciler" olmak 6 kategori altında toplanmıştır. Yarıyapılandırılmış görüşmeler sırasında bir aday birden fazla koda uyan görüş bildirebilmiştir ve bu görüşler uygun olan kodlarla ifade edilmiştir. Bu kategorilerdeki kod dağılımları ise şu şekildedir: Çoktan seçmeli (test) sorularında akademik başarı, kategorisi altında öğretmen adaylarının 57'si "başarılı olduğumu düşünüyorum", 3'ü ise "başarısız olduğumu düşünüyorum" şeklinde görüş belirtmiştir. Bilgilerin hatırlanması kategorisi altında öğretmen adaylarının 51'i "tüm şıkların göz önünde olması sayesinde cevabın hatırlanması", 5'i "şıkların bazılarının ilişkisiz olması sayesinde cevabın hatırlanması" kodlarına uygun olacak şekilde görüş belirtmiştir. Geçmiş kazanımlar kategorisi altında öğretmen adaylarının 47'si "test tekniğine yatkın olma", koduna uygun olacak şekilde görüşlerini açıklamışlardır. İçerik-kapsam kategorisi altında öğretmen adaylarının 29'u "detaylı bilgi gerektirmeme", 18'i ise "test sorusu olabilecek konuyu öngörebilme" kodlarına uygun olacak şekilde görüş belirtmiştir. Şans başarısı kategorisi altında öğretmen adaylarının 27'si "rastgele işaretleme ile doğruya ulaşma imkânı olması" koduna uygun olacak şekilde görüş belirtmiştir. Çeldiriciler kategorisi altında öğretmen adaylarının 3'ü "benzer şıklar arasında çelişki yaşanması koduna uygun olacak şekilde görüşünü ifade etmiştir.

$\mathrm{Bu}$ tip sorulara ilişkin öğretmen adaylarının cevaplarından yapılan doğrudan alıntılara aşağıda verilmiştir.

Öğretmen adayı Ö12, " Şıklardan eleme yoluyla doğru sonuca ulaşabiliyorum, unutsam bile o an şıkları görünce doğru olan cevabı seçebiliyorum, kendimi bu soru tipinde gerçekten başarılı hissediyorum" şeklinde görüş bildirmiştir.

Öğretmen adayı Ö41 ise, "Bu yaşıma kadar bütün önemli sınavlarım çoktan seçmeli sorular ile oldu, üniversiteye dahi böyle girdim ve hayatım boyunca bu şekilde sorulara çalısmaya alıştım bu nedenle bu sorular benim aşina olduğum tarzda ve bu sorularda gerçekten başarılıyım" şeklinde görüş bildirerek çoktan seçmeli soru türündeki sorular hakkındaki görüşünü açıklamıştır. 


\section{Açık Uçlu Soru Türüne İlişkin Görüşler}

Fen bilimleri öğretmen adaylarının, açık uçlu sorulara ilişkin görüşlerini açığa çıkarmaya yönelik yarı yapılandırılmış görüşmelerden elde edilen verilerin betimsel analiz sonuçları Tablo 3'de sunulmuştur.

Tablo 4: Fen Bilimler Öğretmen Adaylarının Açık Uçlu Sorulara İlişkin Görüşleri

\begin{tabular}{|c|c|c|}
\hline Kategori & Kod & Frekans(f) \\
\hline Akademik & Başarılı olduğumu düşünüyorum & 38 \\
\hline \multirow[t]{3}{*}{ Başarı } & Başarısız olduğumu düşünüyorum & 22 \\
\hline & Bu tip soru olarak sorulabilecek sorunun & 24 \\
\hline & içeriğinden az çok belli olması & \\
\hline \multirow[t]{5}{*}{ İçerik- Kapsam } & Derste özellikle üzerinde yoğunlaşılan & 14 \\
\hline & konunun kapsamlı konunun sorulması & \\
\hline & Tam cevap yazılaması da doğru yazılan & 12 \\
\hline & kısımlara da puan verilebilmesi & \\
\hline & Cevap bilinmiyorsa açık uçlu sorunun & 11 \\
\hline \multirow[t]{3}{*}{ Değerlendirme } & yüksek puan kaybettirmesi & \\
\hline & Cevabın farklı bakış açılarına göre farklı & 3 \\
\hline & yorumlanabilmesi & \\
\hline
\end{tabular}

Tablo 4'te, fen bilimleri öğretmen adaylarının açık uçlu soru türüne ilişkin görüşlerine ait verileri, "Akademik Başarı", "İçerik-Kapsam" ve "Değerlendirme" olmak 3 kategori altında toplanmıştır. Yarı-yapılandırılmış görüşmeler sırasında bir aday birden fazla koda uyan görüş bildirebilmiştir ve bu görüşler uygun olan kodlarla ifade edilmiştir. Bu kategorilerdeki kod dağılımları ise şu şekildedir: Açık uçlu sorularında akademik başarı, kategorisi altında öğretmen adaylarının 38'i "başarılı olduğumu düşünüyorum", 22'si ise "başarısız olduğumu düşünüyorum" şeklinde görüş belirtmiştir. İçerik-kapsam kategorisi altında öğretmen adaylarının 24'ü "bu tip soru olarak sorulabilecek sorunun içeriğinden az çok belli olması", 14 'ü ise "derste özellikle üzerinde yoğunlaşılan konunun kapsamlı konunun sorulması" kodlarına uygun olacak şekilde görüş belirtmiştir. Değerlendirme kategorisi altında öğretmen adaylarının 12'si "tam cevap yazılaması da doğru yazılan kısımlara da puan verilebilmesi", 11'i "cevap bilinmiyorsa açık uçlu sorunun yüksek puan kaybettirmesi" ve 3'ü ise "cevabın farklı bakış açılarına göre farklı yorumlanabilmesi" koduna uygun olacak şekilde görüşlerini açıklamışlardır.

Öğretmen adaylarının açık uçlu sorular hakkındaki görüşlerinden alınan, doğrudan alıntılardan bazılarına aşağıda yer verilmiştir.

Öğretmen adayı Ö7, "Bu tür sorularda ben başarılıyım çünkü hocamız ders anlatırken neyin üzerinde ne kadar duruyor dikkat ediyorum ve o strada notlar alıyorum, zaten bu sayede de bu soruları rahatlıkla yapabiliyorum" şeklinde görüşünü belirtmiştir. 
Öğretmen adayı Ö29 ise, "Tüm konuları önüme alıp hangisinin açık uçlu olabileceğini ayırt edebiliyorum, bu soruların cevaplarının özellikle uzun cevap olacağından yola çıkarak tahminler yürütebildiğim için bu soru tipinde başarılı olduğumu düşünüyorum" ifadesi ile görüşünü belirtmiştir.

Öğretmen adayı Ö39 ise, "Ben bu soruları sevemedim ve maalesef çok zamanda yapamıyorum, diyelim cevabı bilmiyorsam bu soruların puanı genellikle yüksek olduğu için oldukça düşük puan almama neden oldukları için benim başarısız olmama neden oluyorlar" şeklinde görüş bildirerek açık uçlu soru türündeki sorular hakkındaki görüşünü belirtmiştir.

\section{Tartışma, Sonuç ve Öneriler}

$\mathrm{Bu}$ çalışma, fen bilimleri öğretmen adaylarının, lisans seviyesindeki biyoloji dersi sınavlarındaki soru tiplerine yönelik görüşlerinin belirlenmesi amacıyla gerçekleştirilmiştir. Araştırma ile fen bilimleri öğretmen adaylarının doğru-yanlış, boşluk doldurma, çoktan seçmeli ve açık uçlu soru türlerine yönelik görüşleri belirlenmiştir.

Öğretmen adaylarından elde edilen görüşler doğrultusunda, adayların büyük bir çoğunluğunun ( $\mathrm{f}=49)$ doğru-yanlış soru tipinde kendilerini akademik olarak başarılı gördükleri sonucu açığa çıkmıştır. Öğretmen adayları doğru-yanlış soru türünde, yanlış veya doğru olarak verilen bilginin tamamının okunmasının doğru cevaba ulaşılmasında kolaylık oluşturulduğunu belirtmişlerdir. Bu soru türünde cümlelerin tamamının verilmiş olmasının, cevaplayıcı tarafından avantaj sağladığı açıklanmıştır. Verilen bilginin okunmasıyla beraber kolaylıkla hatırlanması ve detay bilgi gerektirmemesi doğru cevaba ulaşılmasında öğrenci lehine sonuçlar vermektedir. Kavrama düzeyinde öğretilen bilgilerin ya da kesin bilgi içeren cümlelerin doğru-yanlış sorusu olarak öğrencilere sorulmasının bu fikri edinmelerine neden olduğu düşünülmektedir. Buradan hareketle, öğretmen adaylarının doğru-yanlış sorularında yer verilen soru cümlelerini okuyarak anımsamalarına ve kolaylıkla doğru cevaba erişebilmelerine katkı sağladığına ilişkin çalışmalar literatürde de bulunmaktadır. Şanlı ve Pınar (2017) tarafından gerçekleştirilen bir çalışmada doğru-yanlış sorularının daha çok bilgi boyutunda olgusal bilgi basamağında ve hatırlama basamağında etkili olduğundan bahsedilmiştir.

Adaylar, doğru -yanlış sorularında cevabın ya doğru ya da yanlış olması sebebiyle tahmin ederek doğru cevaba ulaşmış olduklarını açıklamışlardır. Bu tür sorularda cevaplayıcının iki seçeneğinin olması dolayısıyla da tahmin etme şansının ortaya çıkmasının kaçınılmaz olacağ söylenebilir. "Doğru yanlış sorularında verilmiş olan önermelerin bir kısmının yanlış bir kısmının ise doğru olması öğrencinin tahmin etme şansını doğurmaktadır"(Uymaz, 2016) ifadesinin öğretmen adaylarının görüşleriyle örtüşmektedir. Öte yandan ilköğretimde öğretmen ve öğrencilerin ölçme ve değerlendirmeye ilişkin görüşlerinin belirlenmesi amacıyla gerçekleştirilen bir çalışmada öğrencilerin doğru yanlış türlerindeki sorularda doğru cevabi şansla bulma oranının yüksek olduğu sonucuna ulaşılmış olması, çalışmamızın doğru-yanlış soru tiplerine yönelik elde dilen görüşleri ile tutarlı olduğunu göstermektedir (Yıldırım ve Semerci, 2006). Atılganda (2009), doğru-yanlış soru türünü; doğru-yanlış şeklinde verilen maddeleri hiç okumadan doğru ya da yanlış olarak işaretleyen bir öğrencinin doğru cevabi bulma şansı yüzde 50'dir, şans eseri doğru yanıtın bulunması diğer soru türlerine göre daha yüksek olduğundan şans başarısı en yüksek soru türüdür, şeklinde ifade etmiştir. Bu durum bir kez daha doğru-yanlış soruları ile karşı karşıya kalınabilecek şans başarısı faktörünün 
kaçınılmaz olduğuna işaret etmektedir. Benzer şekilde, Görgülü-Arı ve Arslan (2019) tarafından gerçekleştirilen çalışmada da fen bilgisi öğretmen adaylarının sınavlarda sorulan doğru-yanlış soru türlerinde şans eseri doğru cevaba ulaştıklarını ifade etmişlerdir. Öğretmen adaylarından elde edilen görüşler doğrultusunda, adayların büyük bir çoğunluğunun boşluk doldurma soru tipinde kendilerini akademik olarak başarısız gördükleri söylenebilir ( $\mathrm{f}=51$ ). Öğretmen adayları boşluk doldurma türü soruların, detaylı bilgi gerektirmesi, konunun tamamına hâkim olma zorunluluğunu ortaya çıkarması ve konu alanının geniş olması nedeniyle başarısızlığa zemin hazırladığını belirtmişlerdir. Bu soru türünde yer alan bilgilerin akılda kalıcılığının ve hatırlanmasının güç olduğu sebebini öne sürerek kolaylıkla cevaplanabilmesi imkânının ortadan kalktığından da bahsetmişlerdir. Kısa cevaplı soru türleri çok fazla kazanımın geniş bir şekilde ölçülmesini sağlar (Uymaz, 2016). Kısa cevaplı soru türlerinden biri olan boşluk doldurma sorularının öğretmen adaylarının görüşlerinde yer verdiği detaylı bilgi ve geniş konu alanı nitelikleriyle örtüşme gösterdiğini söylemek yanlış olmayacaktır. Öğretmen adaylarının bu tür dayanaklar öne sürerek boşluk doldurma sorularının başarısızlıkla sonuçlanabileceğini belirtmişlerdir. Boşluk doldurma türü sorulara olumsuz yaklaşan adayların aksine kendini bu sorularda başarılı gören adaylar da bulunmaktadır. Bu adayların görüşlerine göre, bu tür sorular, sınava tam anlamıyla çalışanı, üstün körü çalışan ile ayırt ettiğini belirtmişlerdir. Bu durum boşluk doldurma sorularının diğer sorulara nazaran daha ayırt edici bir niteliğe sahip olması şeklinde yorumlanabilir. Literatürde de var olan bir araştırmada, boşluk doldurma sorularının diğer sorulara göre daha ayırt edici olduğundan bahsedilmiştir (Akyıldız ve Karadağ, 2018).

Biyoloji öğretmenleri ve öğrenciler ile yapılan bir araştırmada öğretmen ve öğrencilerin paralel bir şekilde biyoloji ders kitaplarının Latince kavramlardan arındırılması ve kitaplarda yer alan Latince kavramların öğrenmeyi güçleştirdiği şeklinde görüş belirttikleri görülmüştür (Çetin ve Başbay, 2014). Aynı şekilde çalışmamızda öğretmen adaylarının biyoloji kavramlarının çoğunun Latince terimlerden oluşması sebebiyle boşluk doldurma tipindeki sorularda cümleyi tamamlayacak doğru sözcüğü bulmakta güçlük çektiklerini ifadeleri etmişlerdir. Bu durumu boşluk doldurma sorularında yeterli başarıya ulaşmalarında engel olarak görmüşlerdir. Dolayısıyla da iki çalışmadan elde edilen bulguların paralellik gösterdiği söylenebilmektedir. Biyoloji alanına yönelik sorulan boşluk doldurma türündeki sorularını genelde tanım gerektiren ve Latince sözcüklere dayalı sorulmasının bu duruma kaynaklık ettiği söylenebilir. Biyoloji içerik bakımından terim sayısının çokluğu ve terimlerin Latince olması sebebiyle anlaşılmasında güçlük çekilen derslerin başında gelmektedir (Güneş ve Güven, 2011) ifadesi aynı şekilde çalışmamızdaki öğretmen görüşleri ile uyumludur. Diğer yandan öğretmen adayları bu tür soruların kuvvetli bir ezber becerisini de beraberinde getirdiğini vurgulamışladır. Oysa yabancı terimlerin, ezberlemeyi güçleştirdiği bilinen bir gerçektir (Dayığlu, Yılmaz, Yıldırım ve Alan, 2018). Dolayısıyla da güçlü bir ezber becerisi gerektirmesi durumunu yabancı terimleri barındırması özelliğiyle ilişkilendirmek yanlış olmayacaktır. Gerçekleştirilen bir çalışmada öğrencilerden biyoloji alanının ezbere dayalı olmasına yönelik veriler elde edilmesi çalışmadaki görüşleri destekler niteliktedir (Kaya ve Gürbüz, 2002). Öğretmen adayları tarafından bu tür sorulara yönelik gerçekleştirilen sınav hazırlıklarının fazlaca zaman alması, derinlemesine bir çalışma gerektirmesi sebebiyle başarısızlığa kapı aralayabileceği açılanmıştır. Ancak bu durumun tam aksine gerçekleştirilen bir çalışmada boşluk doldurma soruların çalışılması sırasında fazladan bir çaba gerekmediği ve daha az zaman harcandığı 
tespit edilmiştir. Bu anlamda bu görüşü savunan öğretmen adayları ile bahsi geçen çalışma bu noktada birbirlerinden ayrışmaktadır (Özdemir ve İlhan-Beyaztaş, 2018).

Öğretmen adaylarından elde edilen görüşler doğrultusunda, çalışmaya katılım sağlayan adayların neredeyse tümünün ( $f=57)$ çoktan seçmeli soru tipinde kendilerini akademik olarak başarılı gördükleri söylenebilir. Öğretmen adayları çoktan seçmeli soru türünde cevap seçeneklerinin verilmesi avantajını kullanarak, seçeneklerde verilen bilgilerden yola çıkarak, soru köküne ilişkin doğru bir cevaba ulaştıklarını açıklamışlardır. Öğretmen adaylarının sınav türüne göre kullandıkları öğrenme yaklaşımlarını benimseme nedenlerine ilişkin gerçekleştirilen bir çalışmada, öğretmen adaylarının çoktan seçmeli soru türü sınavlarda cevap seçeneğini görünce hatırladıklarını bulgusuna ulaşılmıştır (Özdemir ve İlhanBeyaztaş, 2018). Her iki çalışmada da çoktan seçmeli sorularda verilen şıklardan yararlanma bulgusunun elde edilmiş olması, çalışma sonuçlarının bu noktada paralellik gösterdiğine işaret etmektedir. Öte yandan cevap seçeneklerinden, ilgisiz şıkları çıkarıp, eleme yöntemini kullanan öğretmen adayları da mevuttur. Öğretmen adayları soru köküne ilişkin verilen şıkları teker teker eleyerek doğru yanıta ulaştı̆̆ını açıklamışlardır. Çoktan seçmeli testlerde eleme yöntemi ile doğru cevabı bulma ihtimali vardır (Öksüz ve Güven-Demir, 2018). Bu bağlamda şık eleme yönteminin, çoktan seçmeli testlerin doğru cevaplanmasında avantaj oluşturduğu rahatlıkla söylenebilir. Öğretmen adayları konu hakkında yeterli bilgi sahibi olunmasa bile şılardan birinin rastgele işaretlenmesi sonucu elde edilebilecek şans başarısının kaçınılmaz olabileceğini belirtmişlerdir. Literatürde yer alan bir çalışmada, çoktan seçmeli sorularda şans başarısı nedeniyle soruların kolaylıkla cevaplayabildiklerinden bahsedilmiştir (Özdemir ve İlhan-Beyaztaş, 2018). Gültekin (2014) tarafından çoktan seçmeli testlerde öğrencilerin şans eseri doğru cevabı bulma olasılığının var olduğunun ifade edilmesi, öğretmen adayları görüşleri ile tutarlı olarak değerlendirilebilir niteliktedir. Diğer yandan öğretmen adaylarının geçmiş eğitim sistemlerinde test türü sorularla değerlendirilmeleri nedeniyle bu tip soru türüne yatkınlıklarının, başarı gösterebilmeleri üzerinde etkili olduğunu belirtmişlerdir. Çoktan seçmeli testler, ülkemiz kapsaminda gerçekleştirilen genel sınavlar dâhil olmak üzere öğretmenlerin çoğunlukla tercih ettiği sorulardır (Karamustafaoğlu ve Tutar, 2016). Bu doğrultuda test yatkınlığına ilişkin fikir beyan eden öğretmen görüşleri bu bilgi ile uyumluluk göstermektedir.

Öğretmen adaylarından elde edilen görüşler doğrultusunda, çalışmaya katılım sağlayan adaylarının çoğunluğunun ( $\mathrm{f}=38$ ) açı uçlu soru tipinde kendilerini akademik olarak başarılı gördükleri ancak yine azımsanmayacak sayıda öğretmen adayının ( $\mathrm{f}=22$ ) bu konuda kendisini başarısız olarak nitelendirdiği elde edilen sonuçlar arasındadır. Öğretmen adaylarının bu tür sorularda puanlayıcının olumlu ya da olumsuz etkisi sebebiyle başarıya veya başarısızlığa kapı aralanabileceğini açıklamışlardır. Öğretmen adayları, açık uçlu sorulara verilen yanıtın tamamının yazılmadığı veya yanıtın puanlayıcının bakış açısıyla ters düşmesi gibi durumların başarı puanını etkileyebileceğini belirtmişlerdir. Açık uçlu sorulara öğrenciler tarafından verilen cevapların tamamen doğru ya da yanlış olarak belirlenmesinin mümkün olmaması nedeniyle puanlamaya okuyucu öznelliği karışabilmektedir (Uymaz ve Çalışkan, 2019). Diğer yandan puanlayıcılar, açık uçlu sorularda ölçme sonuçlarında meydana gelebilecek hataya yol açan bir değişkenlik kaynağı olarak görülmektedir (Tekin, 2009). Bu ifadelerden yola çıkarak açık uçlu soruların değerlendirilmesinde karşı karşıya kalınabilecek olumsuz etkiler arasında puanlayıcının farklı bakış açısına sahip olabileceği söylenebilir. Dolayısıyla da öğretmen adaylarından elde edilen görüşler bu ifadeler ile 
desteklenmektedir. Öğretmen adayları açık uçlu soruların öğrenmenin ne düzeyde gerçekleştiğinin belirlenmesinde, etkin ölçme-değerlendirme aracı olabileceği fikrini beyan etmişlerdir. "Ölçme ve değerlendirme sürecinde açık uçlu sorular son derece kullanışlıdır",(Bahar vd.,2010) ifadesi literatürde de yer almaktadır. Bu doğrultuda açık uçlu soruların öğretim sürecinde planlanan hedeflerin ölçülmesinde oldukça uygun bir soru türü olduğunu söylemek mümkündür. Öğretmen adayları içerisinde yer alan daha titiz ve verimli çalışan bireyleri diğerlerinden ayırmanın bu soru türü ile sağlanabileceğini düşündüklerini belirten adaylarda bulunmaktadır. Ayrıca öğretmen adayları açı uçlu soru türünde soru sorulabilecek konu alanında geniş olması ve konuya ilişkin fazlaca bilgiye sahip olmayı gerektirmesi ihtiyacını doğurduğunu da ifade etmişlerdir. Ayrıca açık uçlu soruların puanlamasının genellikle fazla olabilmesi nedeniyle cevabın bilinmemesi durumunda puansal olarak kaybın büyük olacağını düşünen adaylara da rastlanılmıştır. Alan yazında fen bilgisi öğretmen adaylarıyla yapılan bir çalışmada, öğrencilerin açık uçlu sorularının ayrıntılı bilgi gerektirmesi gerekçesiyle bu tür soruların yapılabilmesi için öğrencilerin konu hâkimiyetinin olması ihtiyacına vurgu yapılmıştır (Görgülü-Arı ve Arslan, 2019).

Sonuç olarak, öğrencilerin zihinsel süreçlerini harekete geçirebilmek ve içinde bulunulan durumla ilgili gerekli sorgulamaları yaptırabilmek için soru sorma çok önemli bir sistem olarak karşımıza çıkmaktadır (Çalışkan, 2011). Bu araştırmada bahsi geçen soru türleri ile sorgulanan ölçme, özellikle öğretmen yetiştiren kurumlarda büyük önem arz etmektedir. Bu önem, lisans döneminde yararlanılan soru türleri açısından da kendini göstermektedir. Biyoloji dersinin fen bilgisi öğretmenleri açısından önemi düşünüldügünde gerekli geri bildirimlerin alınabilmesinin bu dersin ölçme sisteminde önemli olabileceği düşülmüştür. Bu bağlamda çalışmada fen bilimleri öğretmen adaylarının görüşleri belirlenerek, lisans dönemindeki ölçme sürecinde yararlanılan soru türleri üzerine de vurgu yapılmıştır.

\section{Öneriler}

Araştırma sonuçlarına göre, bu kısımda bazı önerilerde bulunulmuştur. Doğru-yanlış sorularında doğru cevaba ulaşılmasında şans başarısının var olduğundan bahseden görüşlere bu çalışma ile ulaşılmıştır. Ancak kaliteli bir ölçmenin sağlanabilmesi bakımından şans başarının önüne geçilmesinin gerektiği düşünülmektedir. Bu amaçla, bu tür soruların kullanıldığı sınavlarda cevaplayıcılardan doğru veya yanlış olan cümlenin altını çizmesi veya yanlış cümlenin doğrusunun yazılması fikirleri öne sürülebilir. Boşluk doldurma sorularında başarısız olduğunu düşünen adayların fazlalığından yola çıkılarak, soru hazırlayıcıların özellikle biyoloji gibi ezbere oldukça dayalı bir ders için, potansiyel boşluk doldurma sorularının sorulmadan önce derste hazırlık niteliğinde örneklendirmelerinin bolca yapılması ve ders sırasında özellikle kavram bilgisi ve tanım ölçen bu tür sorulara yönelik içeriklerin üzerinde tekrar tekrar durulmasının öğrenciler açısından fayda sağlayacağı düşünülebilir. Biyoloji dersinin içinde olmazsa olmaz Latince kelimler ise mutlaka varsa Türkçe tam karşılıkları, yoksa da anlamsal karşılıkları ile birlikte öğretilebilir ve sınavlarda bu şekilde sorulabilir. Böylelikle ezber anlayışından uzaklaşan öğrenciler boşluk doldurma sorularında bolca karşılaştıkları Latince ifadeleri rahatlıkla yapabileceklerdir. Ülkemizde çoktan seçmeli(test) soru sistemi ile yetişen nesillerin hayatları boyunca bu sisteme aşinalığının değişmeyeceği bir gerçektir. Ancak öğrencilerimizin kendi cümleleri ile kendini ifade edebileceği, yazımının ve akışının kendi iradesinde ilerleyeceği soru tiplerinden de yararlanılarak ölçme yapmanın mümkün olduğu açıktır. Bu soruların özellikle tercih nedenlerinden olan şans başarısının etkin bir ölçme için zayıflatıcı bir yön 
olduğu da söylenebilir. Bunu engellemek için test hazırlayıcıların şans başarısının engellenmesinde, düzeltme formülü kullanılmalıdır. Bu formül testte yer alan doğru-yanlış cevap sayısı ve testte kullanılan seçenek sayısına dayanmaktadır (Tan,2015). Diğer yandan test sorularında yer alan seçenek sayılarını arttırmalıdır ki böylelikle cevaplayıcıların doğru yanıtı tahminle bulma olasılığı azalacaktır (Yazıcıŏglu, 2007).Açık uçlu sorularda puanlayıcı öznelliğinden ortaya çıkabilecek ölçme hatalarının en aza indirilebilmesi açısından, mutlaka her sınav için model bir cevap anahtarı hazırlanabilir ve kâğıtlar soru bazında okunabilir. Değerlendiricinin hazırladığı cevap anahtarının özellikle öğrenciler ile her sınav sonrası aynen paylaşılması, puanlamada adalet duygusunu ve mümkün olduğunca öznel bir değerlendirmenin yapılmadığı hissini öğrencilere verecektir. Ayrıca bu tür sorulardaki puanlama yüzdelerinin tüm sınav sorularına göre yakın oranda bölünmesinin olumlu olacağını düşünülmektedir.

Ölçme ve değerlendirme sürecinde öğrenci başarısının ölçülmesinde tek tip soru türü yerine farklı soru türleri kullanılmalıdır. Öğrencilere sürekli olarak aynı seviyede soruların sorulması öğrencilerin düşünme ve cevap verme yeteneklerinin hep aynı düzeyde kalmasına neden olabileceği düşünülürse ve farklı becerilere sahip öğrencilerin, o grup içinde bulunabileceği göz önüne alınırsa, eğitimcilerin farklı türlerde soru sormaları ve öğrencilerin sorulan her soru türü için kendini hazır hissedecek donanımla sinava girebilmesinin sağlanması gerekmektedir. Ayrıca soru türleri hazırlanırken sınavın uygulanacağı dersin kendine has özellikleri, ölçülen kitlenin gelişim özellikleri ve hazır bulunuşlukları mutlaka göz önünde bulundurulmalıdır.

\section{Kaynakça}

Akyıldız, M. \& Karadağ, N.(2018). Farklı soru türlerinin güçlük ve ayırt edicilik düzeylerinin incelenmesi. Açıöğretim Uygulamaları ve Araştırmaları Dergisi, 4 (1),112-122.

Atılgan, H. (2009). Doğru-Yanlış Testleri. Eğitimde Ölçme ve Değerlendirme. Ankara: Anı Yayincilik.

Bahar, M., Nartgün, Z., Durmuş, S. \& Bıçak, B. (2010). Geleneksel ve tamamlayıcı ölçme ve değerlendirme teknikleri: öğretmen el kitabı. Ankara: Pegem Akademi.

Başol, G. (2015). Eğitimde ölçme ve değerlendirme. Ankara: Pegem Akademi.

Benzer, A. \& Eldem, E. (2013). Türkçe ve edebiyat öğretmenlerinin ölçme ve değerlendirme araçları hakkında bilgi düzeyleri. Kastamonu Ĕ̆itim Dergisi, 21(2), 649-664.

Birgili, B. (2014). Open Ended Questions As An Alternatıve To Multiple Choice: Dilemma in Turkish Examination System((Doctoral dissertation,Middle East Technical University).Retrieved fromhttp://etd.lib.metu.edu.tr/upload/12617861/index.pdf

Budak, S. (2019). Fen bilimleri eğitiminde kullanılan açı uçlu soruların puanlanmasında puanlayıcılar arasındaki ilişkinin incelenmesi. (Yüksek Lisans Tezi, Ağrı İbrahim Çeçen Üniversitesi, Ağr1). Erişim adresi: http://tez2.yok.gov.tr/

Büyüköztürk, Ş. Kılıç-Çakmak, E., Akgün Ö. E., Karadeniz Ş., Demirel F. (2008). Bilimsel araştırma yöntemleri. Anakara: Pegem A Yayıncilık.

Creswell, J.W. (2013). Araştırma deseni (Çeviri Editörü:Selçuk Beşir Demir). Ankara: Eğiten Kitap.

Çalışkan, H. (2011). Öğretmenlerin hazırladı̆̆ı sosyal bilgiler dersi sınav sorularının değerlendirilmesi. Eğitim ve Bilim Dergisi, 36 (160), 120-132.

Çepni, S.(2015).Kuramdan uygulamaya fen ve teknoloji ögrretimi. Ankara: Pegem A Yayıncılık. 
Çetin, Y. \& Başbay, M., (2014).Öğretmen ve öğrenci gözüyle on ikinci sınıf biyoloji dersi öğretim programı.Pamukkale Üniversitesi Ĕgitim Fakültesi Dergisi, 2015 (38), 16-130.

Dayığlu, H., Yılmaz, A., Yıldırım, K. \& Alan, F. (2019). Kütahya Dumlupınar Üniversitesinde sayısal ve sözel alanlarda öğrenim gören öğrencilerin genel biyoloji ile ilgili kavramlara olan farkındalıkları ve karşılaştırılması. Dumlupinar Üniversitesi Fen Bilimleri Enstitüsü Dergisi, 42, 1-18.

Diken, E \& Yürük, N. (2019). 9. Sınıf öğrencilerinin fen bilimleri alanındaki çoktan seçmeli soruların çözümü öncesi, esnası, sonrasında kullandıkları bilişsel ve üstbilişsel stratejilerin belirlenmesi. Insan ve Toplum Bilimleri Araştırmaları Dergisi, 8(2), 1071-1099.

Erişti, S.D.(2014). Uluslararası Erasmus programı çerçevesinde Türkiye'ye gelen sanat ve tasarım öğrencilerinin Türk kültürü algıları. Anadolu Journal of Eductional Sciences International, 4(2), 82-107.

Gaitas, S. \& Alves Martins, M. (2017). Teacher perceived difficulty in implementing differentiated instructional strategies in primary school. International Journal Of Inclusive Education, 21(5), 544-556.

Gelbal, S. (2013). Ölçme ve değerlendirme. Eskişehir: Anadolu Üniversitesi Açıköğretim Fakültesi Yayınları, No:1802.

Görgülü Arı, A. \& Arslan, K. (2019). Fen Bilgisi Öğretmen Adaylarının Anatomi Dersi Sınavlarında Uygulanan Soru Tiplerine Yönelik Görüşleri. International Journal of Social Science Research , 8 (2) , 185-205.

Güler, N. (2014). Analysis of open-ended statistics questions with many facet rasch model. Eurasian Journal of Educational Research, 55, 73-90.

Güler, N. (2017). Eğitimde Ölçme ve Değgerlendirme (10.Baskı). Ankara: Pegem Akademi.

Gültekin, S. (2014). Performans dayanaklı değerlendirme. Demirtaşlı R. N (Ed.), Eğitimde Ölçme ve değerlendirmeiçinde. Ankara: Edge Akademi.

Güneş, G \&Güven, T. (2011). Biyoloji öğretiminde yabancı terim sorunu. Türk Eğitim Bilimleri Dergisi, 9(4), 775-798.

İlhan, M. (2015). Standart ve SOLO taksonomisine dayalı rubrikler ile puanlanan açık uçlu matematik sorularında puanlayıcı etkilerinin çok yüzeyli Rasch modeli ile incelenmesi. (Doktora Tezi, Gaziantep Üniversitesi, Gaziantep). http://tez2.yok.gov.tr/

Johnson, A.P. (2014). Veri Toplama Yöntemleri, Y. Uzuner \& M. Anay-Özten, (Çev. Ed.) Eylem Araştırması El Kitabı içinde (S.79-105) Ankara: Anı.

Karaca, E.T.(2012). İlköğretim 5. sınf öğrencilerinin rutin olmayan açık uçlu problem çözümlerinin incelenmesi. (Yüksek Lisans Tezi, Gazi Üniversitesi, Ankara).http://tez2.yok.gov.tr/

Karamustafaoğlu, S. \& Tutar, M. (2016). 6. Sınıf Dünya'mız, Ay ve yaşam kaynağımız Güneş ünitesi'ne yönelik bir başarı testi geliştirme. Pegem Atıf İndeksi, 303-320.

Karasar, N. (2016). Bilimsel araştırma yöntemi: kavramlar ilkeler teknikler. Ankara: Nobel Akademik Yayıncılık.

Kaya-Uyanık, G. ve Çalışkan, H. (2015). Sosyal bilgilerde ölçme ve değerlendirme. C. Dönmez, C. ve K. Yazıcı. (Ed.) Sosyal bilgiler öğretimi (s.303-348). Ankara: Salmat Basım Yayıncilik.

Kaya, E. \& Gürbüz, H. (2002). Lise ve meslek lisesi öğrencilerinin biyoloji öğretiminin sorunlarına ilişkin görüşleri. Erzincan Eğitim Fakültesi Dergisi, 4(2), 11-21.

Klufa, J. (2015). Multiple choice question tests -advantages and disadvantages. Retrieved from http://www.inase.org/library/2015/zakynthos/bypaper/EDU/EDU-07.pdf

Milli Eğitim Bakanlığı, Talim ve Terbiye Kurulu Başkanlığı, (2005). İlköğretim sosyal bilgiler öğretim programı ve kılavuzu (6.-7. sınıflar). Devlet Kitapları Müdürlüğü, Ankara. 
Merriam,S.B.(2013). Nitel Araştırma: Desen ve Uygulama için Bir Rehber. Ankara: Nobel Yayınları.

Miles, M, B. \& Huberman, A. M. (1994). Qualitative data analysis: an expanded sourcebook. Thousand Oaks, CA: Sage.

Öksüz, Y. \&Güven Demir, E. (2019). Açık uçlu ve çoktan seçmeli başarı testlerinin psikometrik özellikleri ve öğrenci performansı açısından karşılaştııılması. Hacettepe Üniversitesi Ĕ̆itim Fakültesi Dergisi, 34(1), 259-282.

Özdemir, B. \& İlhan Beyaztaş, D. (2018). Öğretmen adaylarının sınav türüne göre kullandıkları öğrenme yaklaşımlarını benimseme nedenlerine ilişkin görüşleri. Mehmet Akif Ersoy Üniversitesi Ĕ̆itim Fakültesi Dergisi, (46), 363-385.

Patton, M. Q. (2014). Qualitative research \& evaluation methods; integrating theory and practice, Utilization-Focused Evaluation, Saint Paul, MN.

Punch, K. F. \&Oancea, A. E. (2014), Introduction to research methods in education, Sage Publications.

Şanlı, C. \& Pinar, A. (2017). Sosyal bilgiler dersi sınav sorularının yenilenen Bloom taksonomisine göre incelenmesi. İlköğretim Online, 16(3), 949-959.

Tan, S., Kayabaşı, Y. \& Erdoğan, A., (2002).Öğretimi planlama ve değerlendirme. Ankara: Anı Yayıncilı.

Tan, Ş.(2015).Öğretimde ölçme değerlendirme. Ankara: Pegem A Yayıncılık.

Tekin, H. (2009). Eğitimde ölçme ve değerlendirme. Ankara: Yarg1 Yayınevi.

Turgut, M. F. \& Baykul, Y. (2012). Eğitimde ölçme ve değerlendirme. Ankara: Pegem Akademi.

Uymaz, M. (2016). Öğretmen yapımı Sosyal Bilgiler dersi stnav sorularının soru türleri, kapsam geçerliği ve yenilenmiş Bloom taksonomisine göre incelenmesi. (Yüksek Lisans Tezi, Sakarya Üniversitesi, Sakarya).http://tez2.yok.gov.tr/

Uymaz, M. \& Çalışkan, H. (2019). Öğretmen yapımı sosyal bilgiler dersi sınav sorularının yenilenmiş Bloom taksonomisine göre incelenmesi. Kastamonu Ĕ̆itim Dergisi, 27(1), 331346.

Yazıcıoğlu, E. B. (2007). Çoktan seçmeli testler ile yapılandırılmış gridlerin psikomotor özellikler açısıından karşılaştırılması.(Yüksek Lisans Tezi, Ankara Üniversitesi, Ankara).http://tez2.yok.gov.tr/

Yıldırım, A. \&Semerci, Ç. (2006). İlköğretimde (6., 7., 8. Sınıflar) öğretmen ve öğrencilerin ölçme ve değerlendirmeye ilişkin görüşleri (Diyarbakır ve Elazığ ili örneği). Fırat Üniversitesi Sosyal Bilimler Dergisi, 16(2), 83-95.

Yıldırım, A. \& Şimşek, H. (2016). Sosyal bilimlerde nitel araştırma yöntemleri. Ankara: Seçkin Yayincilik.

Yılmaz, H. \& Sünbül, A. M. (2000). Öğretimde planlama ve değerlendirme. Konya: Mikro Yayıncilik. 